\title{
OPEN Prediction of an MMP-1 inhibitor activity cliff using the SAR matrix approach and its experimental validation
}

\author{
Yasunobu Asawa ${ }^{1,2}$, Atsushi Yoshimori $^{3}$, Jürgen Bajorath ${ }^{4,5 \bowtie}$ \& Hiroyuki Nakamura ${ }^{1,5 \bowtie}$ \\ A matrix metalloproteinase 1 (MMP-1) inhibitor activity cliff was predicted using the SAR Matrix \\ method. Compound 4 was predicted as a highly potent activity cliff partner and found to possess \\ 60 times higher inhibitory activity against MMP-1 than the structurally related compound 3. \\ Furthermore, pharmacophore fitting of synthesized compounds indicated that the correctly predicted \\ activity cliff was caused by interactions between the trifluoromethyl group at para position in \\ compound 4 and residue ARG214 of MMP-1.
}

Structure activity relationship (SAR) analysis plays an important role in lead optimization to predict increasingly potent analogues. Generally, in the presence of SAR continuity, compound modifications lead to gradual changes in potency ${ }^{1}$. In this case, QSAR methods can be applied for potency prediction of analogues. In contrast, in the presence of SAR discontinuity, small chemical modifications of active compounds might cause significant changes in potency and lead to the formation of activity cliffs ${ }^{2,3}$. In such cases, QSAR methods are not applicable and compound potency is difficult to predict ${ }^{4,5}$. However, existing SAR data might be thoroughly analyzed to predict novel active compounds.

The SAR Matrix (SARM) methodology was developed for systematic analysis of SAR data sets and the prediction of virtual analogues of known active compounds. SARM organizes analogue series and associated SAR information in matrices on the basis of structural relationships between series and reveals activity cliffs $s^{6,7}$. Following the SARM approach, the existing compounds are fragmented in a size-restricted manner by systematic cleavage of exocyclic single bonds. These procedures result in a two-dimensional of core structure and substituent fragments and unexplored combinations of such fragments (virtual analogues). The activity of virtual analogues can be predicted using SARM-based local Free-Wilson models. Previously, it was demonstrated that such predictions can identify novel active compounds ${ }^{8,9}$. Furthermore, SARM modeling and associated local potency predictions might conceivably also be applied to predict new activity cliffs formed by existing compounds and virtual analogs. Herein, we report the SARM-based prediction and experimental verification of a matrix metalloproteinase 1 (MMP-1) inhibitor activity cliff formed by a known inhibitor and a virtual analogue originating from SARM.

\section{Results and discussion}

MMPs, one of the important collagenase families for degrading native collagen, play a central role in all major stages of tumor progression ${ }^{10,11}$. Although various MMP inhibitors have been considered as potential anti-cancer agents, only one drug, doxycycline, has been approved by the US Food and Drug Administration (FDA) for a different therapeutic application, i.e., the prevention of periodontitis ${ }^{12}$. In addition, another compound has entered phase II trials for Kaposi's sarcoma and brain tumors ${ }^{10,13}$. Currently, a variety of MMP-1 inhibitors and their SAR data are available in the ChEMBL database ${ }^{14}$, which provided the basis of our SARM application and activity

\footnotetext{
${ }^{1}$ Laboratory for Chemistry and Life Science, Institute of Innovative Research, Tokyo Institute of Technology, Nagatsuta-cho, Midori-ku, Yokohama 226-8503, Japan. ${ }^{2}$ School of Life Science and Technology, Tokyo Institute of Technology, Nagatsuta-cho, Midori-ku, Yokohama 226-8503, Japan. ${ }^{3}$ Institute for Theoretical Medicine, Inc., 26-1, Muraoka-Higashi 2-chome, Fujisawa, Kanagawa 251-0012, Japan. ${ }^{4}$ Department of Life Science Informatics, B-IT, LIMES Program Unit Chemical Biology and Medicinal Chemistry, Rheinische Friedrich-Wilhelms-Universität, Endenicher Allee 19c, 53115 Bonn, Germany. ${ }^{5}$ These authors contributed equally: Jürgen Bajorath and Hiroyuki Nakamura. ${ }^{\boxplus}$ email: bajorath@bit.uni-bonn.de; hiro@res.titech.ac.jp
} 
(a)

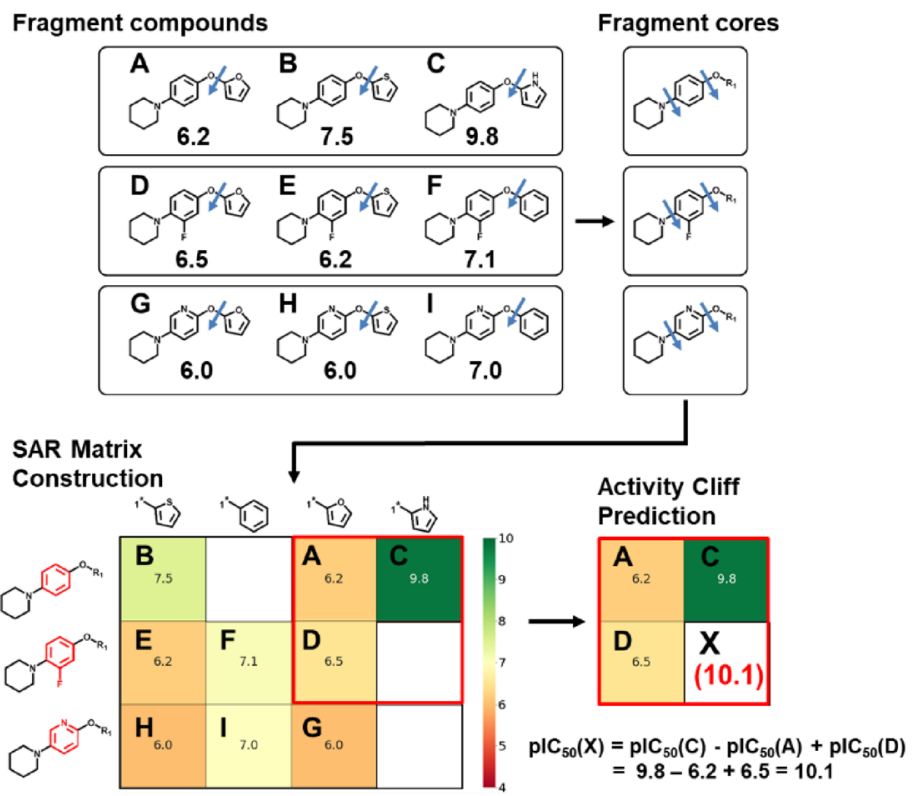

(b)

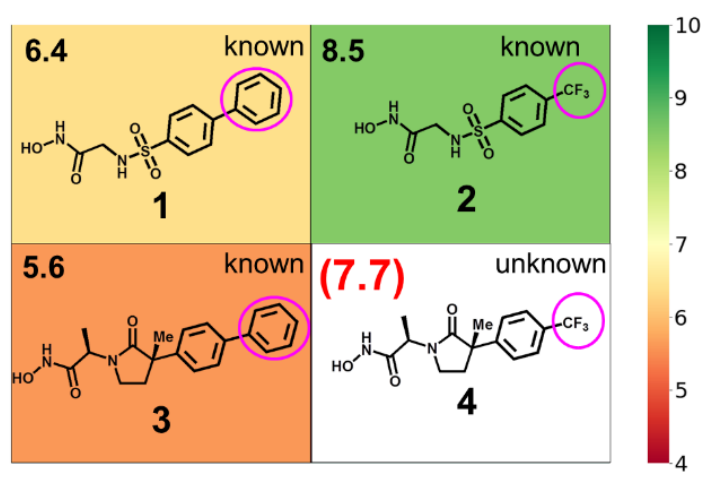

(c)<smiles>CC(C(=O)NO)N1CCC(c2ccc(-c3ccccc3)cc2)C1=O</smiles><smiles>CCC(C)C(=O)N(CC)C(=O)c1ccc(C(F)(F)F)cc1</smiles><smiles>CC(C(=O)NO)N1CCC(c2ccccc2)C1=O</smiles><smiles>CC(C(=O)NO)N1CCC(c2cccc(C(F)(F)F)c2)C1</smiles>

Figure 1. Activity cliff prediction using the SAR matrix (SARM) method. (a) Schematic summary of SARM modeling. (b) Prediction of an activity cliff formed by MMP-1 inhibitors. (c) Structure of designed control compounds.

cliff prediction. To construct SARMs for MMP-1 inhibitors, we first obtained 644 compounds with available $\mathrm{K}_{\mathrm{i}}$ values from ChEMBL (data set ChEMBL332). The MMP-1 inhibitor set yielded 2,697 individual SARMs that were searched for regions of SAR discontinuity as described ${ }^{7}$, (i.e., regions existing analogues have large potency variations). In these regions, the potency of virtual analogues was predicted using local Free-Wilson models, as illustrated in Fig. 1a. Compound environments were inpected for predictions that would yield activity cliffs formed by weakly potent known inhibitors and virtual analogues predicted to be much more portent. Only a 


\begin{tabular}{|l|l|}
\hline Compound & IC $_{50}[\mu \mathrm{M}]^{\mathrm{a}}$ \\
\hline 3 & $11.5 \pm 1.3$ \\
\hline 4 & $0.18 \pm 0.03$ \\
\hline 5 & $1.54 \pm 0.08$ \\
\hline 6 & $11.1 \pm 0.5$ \\
\hline $3^{\prime}$ & $>100$ \\
\hline $4^{\prime}$ & $>100$ \\
\hline
\end{tabular}

Table 1. MMP-1 inhibitory activity of synthesized compounds. ${ }^{a}$ The compound concentration required for $50 \%$ inhibition $\left(\mathrm{IC}_{50}\right)$ was determined from semi-logarithmic dose-response plots, and the results represent the mean \pm standard deviation of triplicated samples.

limited number of such putative activity cliff constellations were identified and we concentrated on a chemically attractive example where a phenyl ring in a weakly potent inhibitor was replaced by a trifluoromethyl group in a virtual analogue, shown in Fig. 1 b.

Compounds $\mathbf{1}^{15,16}, \mathbf{2}^{17}$, and $\mathbf{3}^{18}$ were known MMP-1 inhibitors included in the ChEMBL data sets. By contrast, virtual compound 4 originated from SARMs, representing a novel combination of a core and substituent extracted from structurally distinct inhibitors, as shown in Fig. 1b. It is emphasized that this compound $\mathbf{4}$ could not have been predicted using conventional QSAR methods on the basis of compound 1, which contains a distinct core structure and substituent, or compound 2, which contains a distinct core. Moreover, the activity cliff formed by compounds 3 and $\mathbf{4}$ could not possibly be predicted on the basis of compound $\mathbf{3}$ alone because the prediction fully depended on the local SARM environment of virtual analogue 4, as also illustrated in Fig. 1b. The potency of compound 4 was predicted to be at least one order of magnitude higher than of compound 3 . This prediction was particularly attractive because the potency of compound 2 was improved $\sim 10$-fold by a corresponding replacement of the phenyl group in compound $\mathbf{1}$ with a trifluoromethyl group. Hence, the formation of an activity cliff by compound 3 and its virtual analogue compound $\mathbf{4}$ was predicted. We also emphasize that the prediction did not depend on prior SAR knowledge or subjective intervention. Instead, the SARM approach systematically generates all matrix neighborhoods containing existing and virtual compounds that are amenable to potency predictions and automatically prioritizes activity cliffs on the basis of potency differences between existing and virtual analogs, as illustrated in Fig. 1b. The formation of activity cliffs generally is a rare event in compound data sets ${ }^{4,5}$ and in the case of MMP1 inhibitors, large numbers of known active compounds and new virtual analogues had to be systematically evaluated to predict the formation of an activity cliff formed by compounds 3 and $\mathbf{4}$.

On the basis of the prediction, we synthesized compound 4 . In addition, compounds $\mathbf{3}^{\prime}$ and $\mathbf{4}^{\prime}$, which were the diastereomers of $\mathbf{3}$ and $\mathbf{4}$, respectively, were also synthesized in order to investigate the effect of stereochemical differences on the activity. Compound $\mathbf{5}^{18}$, in which the phenyl group of $\mathbf{3}$ was replaced by hydrogen atom, and compound 6, in which the trifluoromethyl group of 4 was substituted at meta position, were also synthesized as control compounds for comparison (Fig. 1c).

Synthesis of compounds 3-6 is summarized in Scheme 1.18 Esters 7-10 were chosen as starting materials to be treated with lithium diisopropyl amide (LDA) in THF to introduce methyl and allyl groups stepwise at $\alpha$ position of each ester, and the resulting allylic esters were converted to the corresponding aldehydes 11-14 by ozonolysis. Reductive amination of the aldehydes 11-14 with D-alanine methyl ester followed by lactamization was carried out in the presence of zinc dust in acetic acid under reflux conditions in one pot to give the corresponding $\gamma$-lactams 15-18 in 29-49\% yields with a 1:1 diastereomer ratio. After the diastereomers were separated by chromatography, $\gamma$-lactams $15-18$ were converted into $N$-hydroxyamides 3-6 using $\mathrm{NH}_{2} \mathrm{OH}$ and $\mathrm{KOH}$ in $43-98 \%$ yields.

We next examined the inhibitory activity of the synthesized compounds 3-6 against MMP-1 using a colorimetric assay. This assay was performed using the MMP-1 Inhibitor Screening Assay Kit (ab139443) according to the manufacturer's protocols. The reaction was started by the addition of the diluted MMP-1 substrate. The continuous absorbance of the wells was measured at $\mathrm{A}_{412 \mathrm{~nm}}$ using a microplate reader. The results are summarized in Table 1 . The $\mathrm{IC}_{50}$ value of compound $4\left(\mathrm{IC}_{50}=0.18 \pm 0.03 \mu \mathrm{M}\right)$ was 60 -fold lower than that of compound $3\left(\mathrm{IC}_{50}=11.5 \pm 1.3 \mu \mathrm{M}\right)$, hence confirming the formation of the predicted activity cliff. In contrast, both diastereomers $3^{\prime}$ and $4^{\prime}$ did not display significant inhibitory activity even at a $100 \mu \mathrm{M}$ concentration. On the other hand, the inhibitory activity of compound $\mathbf{5}$, which had no substituent at the phenyl ring, was moderate $\left(\mathrm{IC}_{50}=1.54 \pm 0.08 \mu \mathrm{M}\right)$, indicating that the trifluoromethyl substituent is more favorable than the phenyl group of compound 3, probably due to improved steric/hydrophobic compatibility. Compound 6, which had trifluoromethyl group at meta position, exhibited similar potency $\left(\mathrm{IC}_{50}=11.1 \pm 0.5 \mu \mathrm{M}\right)$ to compound 3 .

To evaluate possible binding interactions between compound 4 and MMP-1, a pharmacophore model was constructed $^{19}$ from the crystal structure of compound SC44463 in complex with MMP-1 (PDB entry 1FBL). SC44463 is a substrate-based inhibitor with a hydroxamic acid moiety, which chelates the active site zinc cation in MMP-1. Here, three pharmacophore features of SC44463 were used including a hydrogen bond acceptor (HA), hydrophobic moiety (Hy), and zinc binding location features (ZL) (Fig. 2a). The zinc-chelating and hydrophobic interactions with the S1' pocket, which is sequence-variable within the MMP family, are related to potency and selectivity of MMP inhibitors ${ }^{19,20}$. Although compounds synthesized in Scheme 1 were racemic, the $(R, S)$ enantiomer of compound 4 was superimposed on SC44463 pharmacophore model and putative interactions were refined (Fig. 2b). 
a)

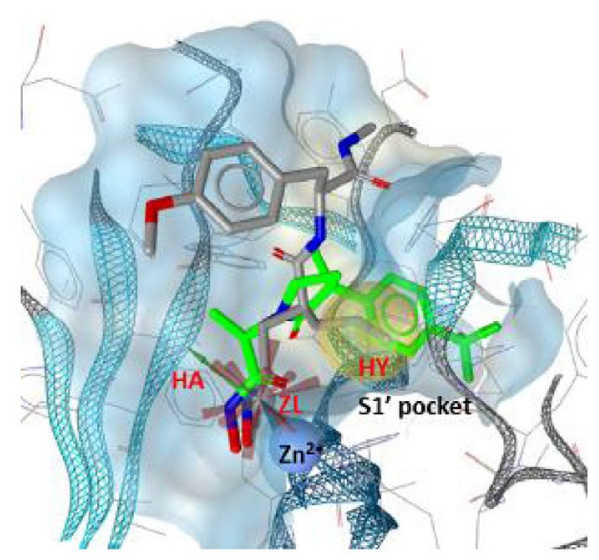

b)

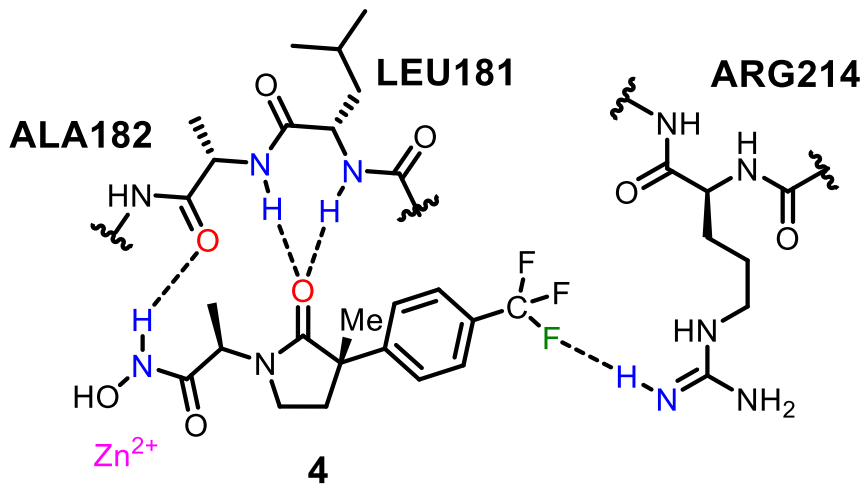

Figure 2. (a) Pharmacophore fitting of compound 4 to the SC44463 pharmacophore model; (b) Binding interaction of compound 4 with MMP-1.
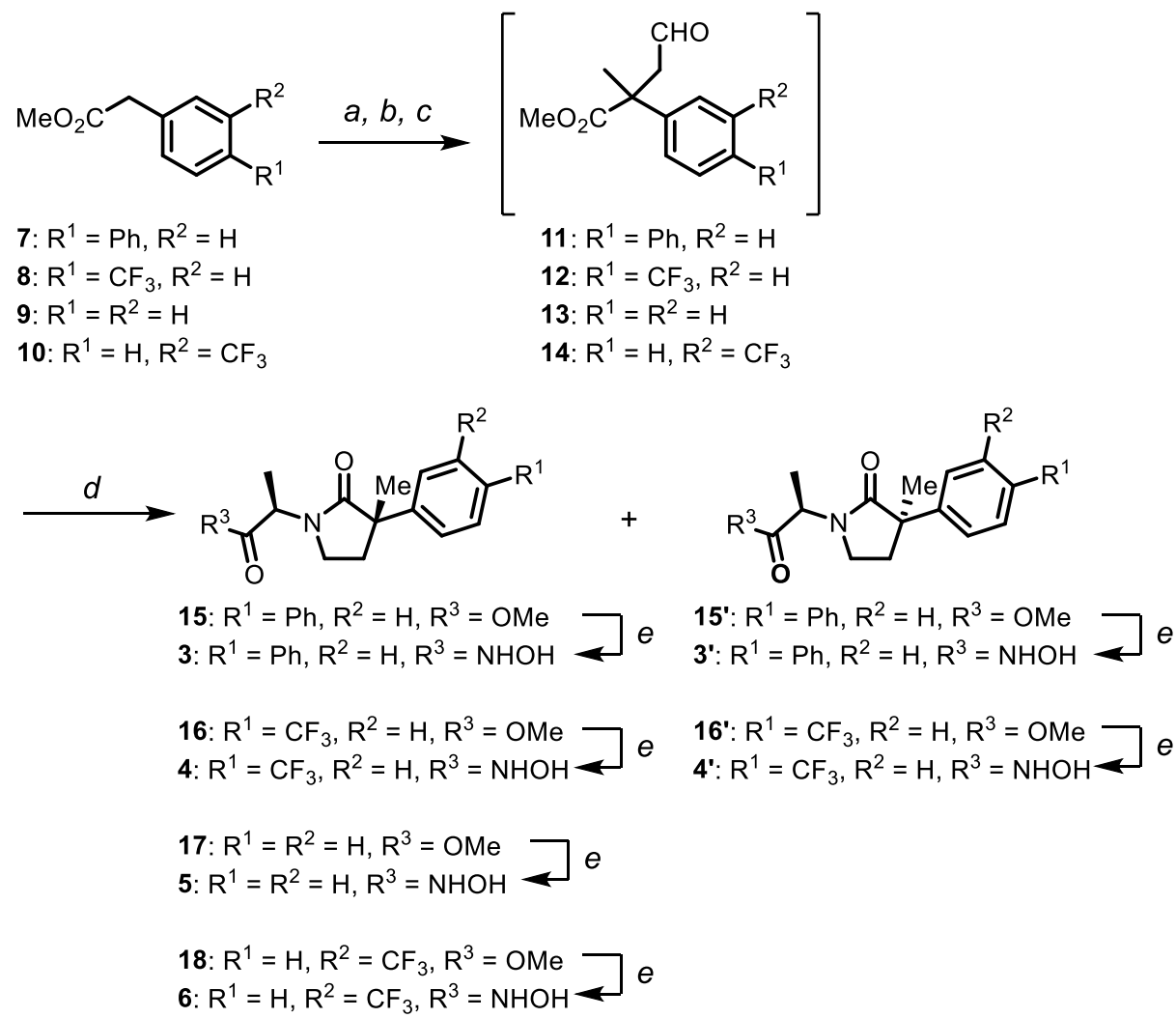

Scheme 1. Synthesis of compounds 3-6. Conditions: (a) LDA, MeI, THF, $-78^{\circ} \mathrm{C}$; (b) LDA, allyl bromide, THF, $-78^{\circ} \mathrm{C}$; (c) $\mathrm{O}_{3}, \mathrm{CH}_{2} \mathrm{Cl}_{2}, \mathrm{PPh}_{3}-78{ }^{\circ} \mathrm{C}$ to r.t.; (d) ${ }_{\mathrm{D}}$-alanine methyl ester, $\mathrm{Zn}$, acetic acid, reflux (15: 29\%; 16: 47\%; 17: 49\%; 18: $29 \%$ yield for 4 steps; d.r. = 1:1); (e) $\mathrm{NH}_{2} \mathrm{OH}, \mathrm{MeOH}\left(3: 72 \% ; 3^{\prime}:\right.$ : 98\%; 4: 90\%; 4': 72\%; 5: 49\%; 6: $43 \%$ yield).

As a result, the trifluoromethyl phenyl group of compound 4 was placed into the hydrophobic S1' pocket where the isobutyl group of SC44463 was located. Considering this model, the biphenyl group of compound 3 was thought to be too bulky to optimally match the S1' pocket (see Figure S1 of the supporting information). Also, compound 4 might form a halogen bonding interaction involving the trifluoromethyl group and residue ARG214 of MMP-1 (with a calculated distance of $\sim 2.5 \AA$; see Figure S2a) in the supporting information for details). On the other hand, both $(R, R)$-diastereomers $\mathbf{3}^{\prime}$ and $\mathbf{4}^{\prime}$, exhibited significantly lower inhibitory activity 
toward MMP-1 $\left(\mathrm{IC}_{50}>100 \mu \mathrm{M}\right)$ than $(R, S)$-isomers 3 and 4. In fact, the carbonyl group of the $\gamma$-lactam is expected to play an important role for the MMP-3 inhibitory activity through hydrogen bond formation with the backbone of residues LEU164 and ALA165 ${ }^{18}$. Consistent with this notion, our model suggested hydrogen bond formation between the $\gamma$-lactam of compound 4 with LEU181 and ALA182 in MMP-1 (with calculated length of 2.9 and $\sim 2.8 \AA$, respectively; see Figure S2b of the supporting information for details), whereas this hydrogen bond formation could not be observed for isomer $4^{\prime}$ (Figure S1).

\section{Conclusion}

We have investigated activity cliff formation based on SARM analysis targeting MMP-1 inhibitors. Compound 4 was selected as a virtual candidate for activity cliff formation on the basis of a thorough search using SARMs. Subsequently, compound $\mathbf{4}$ and derivatives were synthesized and examined for MMP-1 inhibitory activity. The predicted compound $\mathbf{4}$ was found to exhibit 60 -fold higher potency than its analogue compound $\mathbf{3}$, thereby confirming the predicted activity cliff. Retrospective pharmacophore analysis was consistent with the prediction and experimental observations, indicating a prominent interaction between the trifluoromethyl group at para position of compound 4 and ARG214 of MMP-1. Our case study and proof-of-concept investigation suggests that SARM-based analysis of compounds and associated SAR data extends the spectrum of compound design methods and enables the prediction of potent compounds and activity cliffs, representing scientifically stimulating and practically relevant applications. Further studies will aim to investigate the generalization potential and compound design perspectives suggested by this work. Specifically, our proof-of-concept study indicates that SARM-based virtual analogue populations of compound data sets can be systematically screened for predicted activity cliffs, without subjective intervention, which would not be possible using contemporary QSAR methods. Thus, prediction of activity cliffs can be attempted on a large scale for compounds with any biological activity.

\section{Methods}

General. Compounds 3 and $\mathbf{5}$ were known and synthesized according to the literature procedures ${ }^{18}$. Purity of the compounds tested for MMP-1 inhibitory assay was determined by HPLC analysis using Inertsil ODS-3 $5 \mu \mathrm{m}(4.6 \times 75 \mathrm{~mm}$; GL Science) with a linear gradient of $0.1 \%$ formic acid in water $/ 0.1 \%$ formic acid in $\mathrm{MeCN}$ (100/0 to $0 / 100$ for $10 \mathrm{~min})$.

Synthesis of methyl (2R)-2-(3-methyl-2-oxo-3-(4-(trifluoromethyl)phenyl)pyrrolidin-1-yl)propanoate (16)

To a solution of methyl 2-(4-(trifluoromethyl)phenyl)acetate $(8)(579 \mathrm{mg}, 2.56 \mathrm{mmol})$ in THF $(7.5 \mathrm{~mL})$, was slowly added LDA $1.0 \mathrm{M}$ solution in hexane/THF $(1: 2)(3.30 \mathrm{~mL}, 3.30 \mathrm{mmol})$ at $-78^{\circ} \mathrm{C}$. After the resulting mixture was stirred at $0{ }^{\circ} \mathrm{C}$ under argon atmosphere for $1 \mathrm{~h}, \mathrm{MeI}(319 \mu \mathrm{L}, 5.12 \mathrm{mmol})$ was added. Then, the resulting mixture was stirred at room temperature for $1 \mathrm{~h}$. After that, the reaction mixture was concentrated under pressure. Brine was added to the mixture and the product was extracted with ethyl acetate, dried over sodium sulfate, and concentrated under vacuum. The crude product was used in the next step without further purification.

To a solution of the crude material in THF $(7.5 \mathrm{~mL}), \mathrm{x}$ LDA $1.0 \mathrm{M}$ solution in hexane/THF $(1: 2)(3.30 \mathrm{~mL}$, $3.30 \mathrm{mmol})$ at $-78^{\circ} \mathrm{C}$ was slowly added. After the mixture was stirred at $0{ }^{\circ} \mathrm{C}$ under argon atmosphere for $1 \mathrm{~h}$, allyl bromide $(433 \mu \mathrm{L}, 5.12 \mathrm{mmol})$ was added. The resulting mixture was stirred at room temperature for $1 \mathrm{~h}$ and the reaction mixture was concentrated under reduced pressure. The reaction was quenched with brine and the mixture was extracted with EtOAc, washed with hexane, dried over sodium sulfate, and concentrated under vacuum. The crude product was used in the next step without further purification.

Ozone was pumped into a $-78{ }^{\circ} \mathrm{C}$ solution of the above crude material in $\mathrm{CH}_{2} \mathrm{Cl}_{2}(5 \mathrm{~mL})$ until the starting material disappeared, as monitored by TLC analysis. The mixture was purged with argon. Triphenylphosphine $(806 \mathrm{mg}, 3.07 \mathrm{mmol}$ ) was added. After $1 \mathrm{~h}$ at room temperature, the mixture was concentrated under vacuum. Purification by short column chromatography on silica gel (20\% EtOAc in Hexane) gave the crude product 12 which was used to the next step without further purification.

To a solution of the above product (12) and D-alanine methyl ester hydrochloride $(275 \mathrm{mg}, 1.97 \mathrm{mmol})$ in acetic acid $(10.7 \mathrm{~mL})$ was added portion-wise zinc powder $(1.17 \mathrm{~g}, 17.9 \mathrm{mmol})$. The mixture was heated to reflux for $12 \mathrm{~h}$, and then cooled to room temperature. Following addition of $\mathrm{CH}_{2} \mathrm{Cl}_{2}$, the mixture was filtered and the filter cake washed with methanol/ $\mathrm{CH}_{2} \mathrm{Cl}_{2}$. The filtrate was concentrated at $45^{\circ} \mathrm{C}$ in vacuo to remove acetic acid. The residue was treated with ethyl acetate and filtered to remove insoluble materials. The filtrate was concentrated and purified by column chromatography on silica gel (40\% EtOAc in hexane) to afford $179 \mathrm{mg}$ of fast eluting isomer $\left(\mathbf{1 6}^{\prime}\right), 135 \mathrm{mg}$ of slow eluting isomer (16), and $80 \mathrm{mg}$ of mixture containing a mixture of both isomers (total $394 \mathrm{mg}, 1.20 \mathrm{mmol}, 47 \%$ yield for 4 steps) as a colorless oil.

16: ${ }^{1} \mathrm{H}$ NMR (400 MHz; $\left.\mathrm{CDCl}_{3}\right): \delta 7.60(\mathrm{~d}, J=8.8 \mathrm{~Hz}, 2 \mathrm{H}), 7.56(J=8.8 \mathrm{~Hz}, 2 \mathrm{H}), 4.97(\mathrm{q}, J=7.5 \mathrm{~Hz}, 1 \mathrm{H}), 3.69$ $(\mathrm{s}, 3 \mathrm{H}), 3.41(\mathrm{q}, J=4.5 \mathrm{~Hz}, 2 \mathrm{H}), 2.48-2.41(\mathrm{~m}, 1 \mathrm{H}), 2.23-2.16(\mathrm{~m}, 1 \mathrm{H}), 1.58(\mathrm{~s}, 3 \mathrm{H}), 1.48(\mathrm{~d}, J=7.2 \mathrm{~Hz}, 3 \mathrm{H}) ;{ }^{13} \mathrm{C}$ NMR (125 MHz; $\left.\mathrm{CDCl}_{3}\right): \delta 177.3,171.9,147.9,129.1(\mathrm{q}, J=32.3 \mathrm{~Hz}), 126.7,125.6(\mathrm{q}, J=180.1 \mathrm{~Hz}), 125.5(\mathrm{q}$, $J=3.6 \mathrm{~Hz}), 52.5,49.8,48.9,40.6,35.3,24.5,15.0 ;{ }^{19} \mathrm{~F} \mathrm{NMR}\left(470 \mathrm{MHz}, \mathrm{CDCl}_{3}\right): \delta 62.5$; HRMS (ESI, positive) for $\mathrm{C}_{16} \mathrm{H}_{18} \mathrm{~F}_{3} \mathrm{NO}_{3}(\mathrm{~m} / \mathrm{z})$ : calculated $352.1131(\mathrm{M}+\mathrm{Na})^{+}$, found 352.1128 .

16': ${ }^{1} \mathrm{H}$ NMR $\left(400 \mathrm{MHz} ; \mathrm{CDCl}_{3}\right): \delta 7.59(\mathrm{~d}, J=8.5 \mathrm{~Hz}, 2 \mathrm{H}), 7.56(\mathrm{~d}, J=8.5 \mathrm{~Hz}, 2 \mathrm{H}), 4.93(\mathrm{q}, J=7.5 \mathrm{~Hz}, 1 \mathrm{H})$, $3.75(\mathrm{~s}, 3 \mathrm{H}), 3.53-3.49(\mathrm{~m}, 1 \mathrm{H}), 3.36-3.30(\mathrm{~m}, 1 \mathrm{H}), 2.46-2.39(\mathrm{~m}, 1 \mathrm{H}), 2.30-2.23(\mathrm{~m}, 1 \mathrm{H}), 1.58(\mathrm{~s}, 3 \mathrm{H}), 1.45$ $(\mathrm{d}, J=7.5 \mathrm{~Hz}, 3 \mathrm{H}) ;{ }^{13} \mathrm{C}$ NMR $\left(125 \mathrm{MHz} ; \mathrm{CDCl}_{3}\right): \delta 177.3,171.9,147.8,129.0(\mathrm{q}, J=14.9 \mathrm{~Hz}), 126.7,125.5(\mathrm{q}$, $J=3.6 \mathrm{~Hz}), 124.2(\mathrm{q}, J=270.2 \mathrm{~Hz}), 52.4,49.8,48.9,40.6,35.3,24.5,14.9 ;{ }^{19} \mathrm{~F} \mathrm{NMR}\left(470 \mathrm{MHz}, \mathrm{CDCl}_{3}\right): \delta 62.5$; HRMS (ESI, positive) for $\mathrm{C}_{16} \mathrm{H}_{18} \mathrm{~F}_{3} \mathrm{NO}_{3}(\mathrm{~m} / \mathrm{z})$ : calculated $352.1131(\mathrm{M}+\mathrm{Na})^{+}$, found 352.1145 .

Synthesis of $(R)-N$-hydroxy-2-((S)-3-methyl-2-oxo-3-(4-(trifluoromethyl)phenyl)pyrrolidin-1-yl)propanamide (4) Hydroxylamine hydrochloride $(234 \mathrm{mg}, 34 \mathrm{mmol})$ in hot methanol (1.2 $\mathrm{mL})$ was treated with a solution 
of $\mathrm{KOH}(281 \mathrm{mg}, 50 \mathrm{mmol})$ in methanol $(700 \mu \mathrm{L})$. The mixture was cooled to room temperature and the insoluble $\mathrm{KCl}$ was removed by filtration to yield a clear solution (approximately $1.76 \mathrm{M}$ of $\mathrm{NH}_{2} \mathrm{OH}$ ). The freshly prepared hydroxylamine solution $(371 \mu \mathrm{L}, 0.655 \mathrm{mmol})$ was added to a solution of $16(43 \mathrm{mg}, 0.131 \mathrm{mmol})$ in methanol $(500 \mu \mathrm{L})$. The reaction mixture was stirred at room temperature for $25 \mathrm{~min}$ and then adjusted to $\mathrm{pH} 5-6$ by addition of $1 \mathrm{~N} \mathrm{HCl}$ while the flask was cooled on an ice-water bath. The precipitate was collected by filtration, rinsed with methanol/water $(2: 1,500 \mu \mathrm{L})$, water $(500 \mu \mathrm{L})$, and dried under vacuum to give amorphous compound 4 (39 mg, 90\%). ${ }^{1} \mathrm{H}$ NMR (500 MHz; $\left.\mathrm{CD}_{3} \mathrm{OD}\right): \delta 7.63(\mathrm{~d}, J=8.5 \mathrm{~Hz}, 2 \mathrm{H}), 7.59(\mathrm{~d}, J=8.5 \mathrm{~Hz}, 2 \mathrm{H}), 4.65(\mathrm{q}, J=7.2 \mathrm{~Hz}$, $1 \mathrm{H}), 3.61-3.52(\mathrm{~m}, 2 \mathrm{H}), 2.43-2.39(\mathrm{~m}, 1 \mathrm{H}), 2.25-2.20(\mathrm{~m}, 1 \mathrm{H}), 1.55(\mathrm{~s}, 3 \mathrm{H}), 1.43(\mathrm{~d}, J=7.2 \mathrm{~Hz}, 3 \mathrm{H}) ;{ }^{13} \mathrm{C} \mathrm{NMR}$ $\left(125 \mathrm{MHz} ; \mathrm{CD}_{3} \mathrm{OD}\right): \delta 179.3,170.1,149.6,130.0(\mathrm{q}, J=32.1 \mathrm{~Hz}), 128.2(\mathrm{t}, J=14.4 \mathrm{~Hz}), 126.3(\mathrm{q}, J=3.7 \mathrm{~Hz}), 125.7$ (q, $J=269.4 \mathrm{~Hz}), 50.6,50.0,42.3,36.8,24.2,15.2 ;{ }^{19} \mathrm{~F}$ NMR $\left(470 \mathrm{MHz}, \mathrm{CD}_{3} \mathrm{OD}\right): \delta 64.0$; HRMS (ESI, negative) for $\mathrm{C}_{15} \mathrm{H}_{17} \mathrm{~F}_{3} \mathrm{~N}_{2} \mathrm{O}_{3}(\mathrm{~m} / \mathrm{z})$ : calculated $329.1108(\mathrm{M}-\mathrm{H})^{-}$, found 329.1109 ; HPLC purity $99.6 \%$, retention time $7.36 \mathrm{~min}$.

Synthesis of $(R)-N$-hydroxy-2-((R)-3-methyl-2-oxo-3-(4-(trifluoromethyl)phenyl)pyrrolidin-1-yl)propanamide (4') This compound was prepared from ester $16^{\prime}(47 \mathrm{mg}, 0.413 \mathrm{mmol})$ using the procedure described for 4 in $72 \%$ yield as a white solid. m.p. $105-107^{\circ} \mathrm{C}$; ${ }^{1} \mathrm{H}$ NMR $\left(500 \mathrm{MHz} ; \mathrm{CD}_{3} \mathrm{OD}\right): \delta 7.64(\mathrm{~d}, J=8.5 \mathrm{~Hz}, 2 \mathrm{H}), 7.58$ $(\mathrm{d}, J=8.5 \mathrm{~Hz}, 2 \mathrm{H}), 4.63(\mathrm{q}, J=7.2 \mathrm{~Hz}, 1 \mathrm{H}), 3.68-3.63(\mathrm{~m}, 2 \mathrm{H}), 3.48-3.43(\mathrm{~m}, 1 \mathrm{H}), 2.45-2.40(\mathrm{~m}, 1 \mathrm{H}), 2.29-2.25$ $(\mathrm{m}, 1 \mathrm{H}), 1.55(\mathrm{~s}, 3 \mathrm{H}), 1.41(\mathrm{~d}, J=7.2 \mathrm{~Hz}, 3 \mathrm{H}) ;{ }^{13} \mathrm{C}$ NMR $\left(125 \mathrm{MHz}\right.$; $\left.\mathrm{CD}_{3} \mathrm{OD}\right): \delta 179.3,170.1,149.5,130.0$ (q, $J=32.3 \mathrm{~Hz}), 128.1,126.4(\mathrm{~d}, J=3.8 \mathrm{~Hz}), 125.7$ (q, $J=269.5 \mathrm{~Hz}), 50.6,49.9,42.3,36.4,24.2,15.3 ;{ }^{19} \mathrm{~F} \mathrm{NMR}$ (470 MHz, CD $\left.\mathrm{CD}_{3} \mathrm{OD}\right): \delta 64.0$; HRMS (ESI, negative) for $\mathrm{C}_{15} \mathrm{H}_{17} \mathrm{~F}_{3} \mathrm{~N}_{2} \mathrm{O}_{3}(\mathrm{~m} / \mathrm{z})$ : calculated $329.1108(\mathrm{M}-\mathrm{H})^{-}$, found 329.1090; HPLC purity $96.01 \%$, retention time $7.52 \mathrm{~min}$.

Synthesis of methyl (2R)-2-(3-([1,1'-biphenyl]-4-yl)-3-methyl-2-oxopyrrolidin-1-yl)propanoate (15) This compound was prepared from ester methyl 2-([1,1'-biphenyl]-4-yl)acetate (7) (601 mg, $2.76 \mathrm{mmol})$ using the procedure described above for 16 and afforded $156 \mathrm{mg}$ of fast eluting isomer $\left(15^{\prime}\right), 118 \mathrm{mg}$ of slow eluting desired isomer (15) (total yield $274 \mathrm{mg}, 0.812 \mathrm{mmol}, 29 \%$ for 4 steps) as a colorless oil.

15: ${ }^{1} \mathrm{H}$ NMR $\left(400 \mathrm{MHz} ; \mathrm{CDCl}_{3}\right): \delta 7.58-7.55(\mathrm{~m}, 4 \mathrm{H}), 7.49(\mathrm{~d}, J=6.8 \mathrm{~Hz}, 2 \mathrm{H}), 7.41(\mathrm{~d}, J=6.1 \mathrm{~Hz}, 2 \mathrm{H}), 7.31(\mathrm{~d}$, $J=6.1 \mathrm{~Hz}, 2 \mathrm{H}), 4.98(\mathrm{q}, J=5.9 \mathrm{~Hz}, 1 \mathrm{H}), 3.67(\mathrm{~s}, 3 \mathrm{H}), 3.42-3.35(\mathrm{~m}, 2 \mathrm{H}), 2.50-2.45(\mathrm{~m}, 1 \mathrm{H}), 2.19-2.13(\mathrm{~m}, 1 \mathrm{H})$, $1.59(\mathrm{~s}, 3 \mathrm{H}), 1.46(\mathrm{~d}, J=5.9 \mathrm{~Hz}, 3 \mathrm{H}) ;{ }^{13} \mathrm{C} \mathrm{NMR}\left(125 \mathrm{MHz} ; \mathrm{CDCl}_{3}\right): \delta 177.8,172.0,142.7,140.8,139.5,128.8,127.2$, 127.1, 127.0, 126.8, 52.2, 49.6, 48.6, 40.5, 35.9, 24.6, 14.8; HRMS (ESI, positive) for $\mathrm{C}_{21} \mathrm{H}_{23} \mathrm{NO}_{3}(\mathrm{~m} / \mathrm{z}$ ): calculated $360.1570(\mathrm{M}+\mathrm{Na})^{+}$, found 360.1572 .

15': ${ }^{1} \mathrm{H}$ NMR (400 MHz; $\left.\mathrm{CDCl}_{3}\right): \delta 7.58-7.55(\mathrm{~m}, 4 \mathrm{H}), 7.47(\mathrm{~d}, J=6.8 \mathrm{~Hz}, 2 \mathrm{H}), 7.42(\mathrm{~d}, J=6.1 \mathrm{~Hz}, 2 \mathrm{H}), 7.33$ $(\mathrm{d}, J=6.1 \mathrm{~Hz}, 2 \mathrm{H}), 4.97(\mathrm{q}, J=6.0 \mathrm{~Hz}, 1 \mathrm{H}), 3.74(\mathrm{~s}, 3 \mathrm{H}), 3.50-3.46(\mathrm{~m}, 1 \mathrm{H}), 3.36-3.31(\mathrm{~m}, 1 \mathrm{H}), 2.49-2.44(\mathrm{~m}$, $1 \mathrm{H}), 2.27-2.21(\mathrm{~m}, 1 \mathrm{H}), 1.60(\mathrm{~s}, 3 \mathrm{H}), 1.45(\mathrm{~d}, J=6.0 \mathrm{~Hz}, 3 \mathrm{H}) ;{ }^{13} \mathrm{C} \mathrm{NMR}\left(125 \mathrm{MHz} ; \mathrm{CDCl}_{3}\right): \delta 177.9,172.1,142.8$, 140.9, 139.7, 128.8, 127.3, 127.1, 126.6, 52.4, 49.7, 48.6, 40.6, 35.5, 24.7, 15.0; HRMS (ESI, positive) for $\mathrm{C}_{21} \mathrm{H}_{23} \mathrm{NO}_{3}$ $(\mathrm{m} / \mathrm{z})$ : calculated $360.1570(\mathrm{M}+\mathrm{Na})^{+}$, found 360.1573 .

Synthesis of $(R)-2-\left((S)-3-\left(\left[1,1^{\prime}\right.\right.\right.$-biphenyl]-4-yl)-3-methyl-2-oxopyrrolidin-1-yl)- $N$-hydroxypropanamide (3) This compound was prepared from ester $15(58 \mathrm{mg}, 0.172 \mathrm{mmol})$ using the procedure described above for compound 4 in $72 \%$ yield as a white solid: m.p. $160-162{ }^{\circ} \mathrm{C} ;{ }^{1} \mathrm{H}$ NMR was the same as reported ${ }^{18}$; HRMS (ESI, negative) for $\mathrm{C}_{20} \mathrm{H}_{22} \mathrm{~N}_{2} \mathrm{O}_{3}(\mathrm{~m} / \mathrm{z})$ : calculated $337.1547(\mathrm{M}-\mathrm{H})^{-}$, found 337.1547; HPLC purity 99.4\%, retention time $7.96 \mathrm{~min}$.

Synthesis of (R)-2-((R)-3-([1,1'-biphenyl]-4-yl)-3-methyl-2-oxopyrrolidin-1-yl)- $N$-hydroxypropanamide (3') This compound was prepared from ester $15^{\prime}(46 \mathrm{mg}, 0.136 \mathrm{mmol})$ using the procedure described above for compound 4 in $98 \%$ yield as a white solid: m.p. $137-138{ }^{\circ} \mathrm{C} ;{ }^{1} \mathrm{H}$ NMR $\left(500 \mathrm{MHz} ; \mathrm{CD}_{3} \mathrm{OD}\right): \delta 7.59-7.57$ (m, $4 \mathrm{H}), 7.43-7.39(\mathrm{~m}, 4 \mathrm{H}), 7.31(\mathrm{t}, J=7.4 \mathrm{~Hz}, 1 \mathrm{H}), 4.66(\mathrm{q}, J=7.2 \mathrm{~Hz}, 1 \mathrm{H}), 3.65-3.60(\mathrm{~m}, 1 \mathrm{H}), 3.44-3.35(\mathrm{~m}, 1 \mathrm{H})$, 2.45-2.40 (m, 1H), 2.22-2.17 (m, 1H), $1.54(\mathrm{~s}, 3 \mathrm{H}), 1.39(\mathrm{~d}, J=7.2 \mathrm{~Hz}, 3 \mathrm{H}) ;{ }^{13} \mathrm{C}$ NMR $\left(125 \mathrm{MHz} ; \mathrm{CD}_{3} \mathrm{OD}\right): \delta$ $180.0,170.1,143.9,141.8,141.0,129.9,128.4,128.1,127.8,127.7,50.3,49.8,42.3$, 36.7 24.4, 15.3; HRMS (ESI, negative) for $\mathrm{C}_{20} \mathrm{H}_{22} \mathrm{~N}_{2} \mathrm{O}_{3}(\mathrm{~m} / \mathrm{z})$ : calculated $337.1547(\mathrm{M}-\mathrm{H})^{-}$, found 337.1541; HPLC purity 99.20\%, retention time $7.91 \mathrm{~min}$.

Synthesis of methyl (R)-2-((S)-3-methyl-2-oxo-3-phenylpyrrolidin-1-yl)propanoate (17) This compound was prepared from ester methyl 2-phenylacetate (9) $(561 \mu \mathrm{L}, 4.00 \mathrm{mmol})$ using the procedure described above for 16 and afforded $224 \mathrm{mg}$ of fast eluting isomer, $98 \mathrm{mg}$ of slow eluting desired isomer (17), and $190 \mathrm{mg}$ of mixture containing a mixture of both isomers (total yield $512 \mathrm{mg}, 1.96 \mathrm{mmol}, 49 \%$ for 4 steps) as a colorless oil. ${ }^{1} \mathrm{H}$ NMR $\left(400 \mathrm{MHz} ; \mathrm{CDCl}_{3}\right): \delta 7.42(\mathrm{~d}, J=7.2 \mathrm{~Hz}, 2 \mathrm{H}), 7.33(\mathrm{~d}, J=7.6 \mathrm{~Hz}, 2 \mathrm{H}), 7.23(\mathrm{t}, J=7.2 \mathrm{~Hz}, 1 \mathrm{H}), 4.98(\mathrm{q}, J=7.4 \mathrm{~Hz}$, $1 \mathrm{H}), 3.68(\mathrm{~s}, 3 \mathrm{H}), 3.37(\mathrm{t}, J=6.7 \mathrm{~Hz}, 2 \mathrm{H}), 2.49-2.43(\mathrm{~m}, 1 \mathrm{H}), 2.18-2.11(\mathrm{~m}, 1 \mathrm{H}), 1.56(\mathrm{~s}, 3 \mathrm{H}), 1.46(\mathrm{~d}, J=7.4 \mathrm{~Hz}$, $3 \mathrm{H}) ;{ }^{13} \mathrm{C} \mathrm{NMR}\left(125 \mathrm{MHz} ; \mathrm{CDCl}_{3}\right): \delta 177.9,171.9,143.7,128.5,126.8,126.4,52.3,49.7,48.9,40.5,36.1,24.8,14.9$; HRMS (ESI, positive) for $\mathrm{C}_{15} \mathrm{H}_{19} \mathrm{NO}_{3}(\mathrm{~m} / \mathrm{z})$ : calculated 284.1257 $(\mathrm{M}+\mathrm{Na})^{+}$, found 284.1259.

Synthesis of (R)-N-hydroxy-2-((S)-3-methyl-2-oxo-3-phenylpyrrolidin-1-yl)propanamide (5) This compound was prepared from ester $17(65 \mathrm{mg}, 0.249 \mathrm{mmol})$ using the procedure described above for compound 4 in $49 \%$ yield as amorphous material. The structure was determined by comparison with authentic samples prepared by the literature procedure ${ }^{18}$; HPLC purity $96.1 \%$, retention time $6.17 \mathrm{~min}$.

Synthesis of methyl $(R)-2-((S)$-3-methyl-2-oxo-3-(3-(trifluoromethyl)phenyl)pyrrolidin-1-yl)propanoate (18) This compound was prepared from methyl 2-(3-(trifluoromethyl)phenyl)acetate (10) (898 $\mathrm{mg}, 4.12 \mathrm{mmol}$ ) 
using the procedure described above for 16 afforded $21 \mathrm{mg}$ of fast eluting isomer, $96 \mathrm{mg}$ of slow eluting desired isomer (18), and $278 \mathrm{mg}$ of mixture containing a mixture of both isomers (total yield $396 \mathrm{mg}, 1.12 \mathrm{mmol}, 29 \%$ for 4 steps) as a colorless oil. ${ }^{1} \mathrm{H}$ NMR $\left(400 \mathrm{MHz} \mathrm{CDCl}_{3}\right): \delta 7.67-7.64(\mathrm{~m}, 2 \mathrm{H}), 7.50-7.46(\mathrm{~m}, 2 \mathrm{H}), 4.98(\mathrm{q}, J=7.4 \mathrm{~Hz}$, $1 \mathrm{H}), 3.67(\mathrm{~s}, 3 \mathrm{H}), 3.40-3.35(\mathrm{~m}, 2 \mathrm{H}), 2.48-2.42(\mathrm{~m}, 1 \mathrm{H}), 2.24-2.17(\mathrm{~m}, 1 \mathrm{H}), 1.58(\mathrm{~s}, 3 \mathrm{H}), 1.48(\mathrm{~d}, J=7.4 \mathrm{~Hz}, 3 \mathrm{H})$; ${ }^{13} \mathrm{C} \mathrm{NMR}\left(125 \mathrm{MHz} ; \mathrm{CDCl}_{3}\right): \delta 177.1,171.7,144.7,130.7(\mathrm{q}, J=31.8 \mathrm{~Hz}), 130.0,128.9,123.7(\mathrm{q}, J=3.8 \mathrm{~Hz}), 123.6$ $(\mathrm{q}, J=3.8 \mathrm{~Hz}), 124.2(\mathrm{q}, J=270.8 \mathrm{~Hz}), 52.3,49.6,48.8,40.4,35.7,24.7,14.7 ;{ }^{19} \mathrm{~F} \mathrm{NMR}\left(470 \mathrm{MHz}, \mathrm{CDCl}_{3}\right): \delta 62.4$; HRMS (ESI, positive) for $\mathrm{C}_{16} \mathrm{H}_{18} \mathrm{~F}_{3} \mathrm{NO}_{3}(\mathrm{~m} / \mathrm{z})$ : calculated $352.1131(\mathrm{M}+\mathrm{Na})^{+}$, found 352.1135 .

Synthesis of (R)- $N$-hydroxy-2-((S)-3-methyl-2-oxo-3-(3-(trifluoromethyl)phenyl)pyrrolidin-1-yl)propanamide (6) This compound was prepared from ester $18(67 \mathrm{mg}, 0.204 \mathrm{mmol})$ using the procedure described above for compound 4 in $43 \%$ yield as amorphous material. ${ }^{1} \mathrm{H}$ NMR $\left(500 \mathrm{MHz} ; \mathrm{CD}_{3} \mathrm{OD}\right): \delta 7.74(\mathrm{~s}, 1 \mathrm{H}), 7.66$ $(\mathrm{d}, J=7.2 \mathrm{~Hz}, 1 \mathrm{H}), 7.56-7.51(\mathrm{~m}, 2 \mathrm{H}), 4.64(\mathrm{q}, J=7.2 \mathrm{~Hz}, 1 \mathrm{H}), 3.62-3.53(\mathrm{~m}, 2 \mathrm{H}), 2.44-2.39(\mathrm{~m}, 1 \mathrm{H}), 2.27-2.12$ $(\mathrm{m}, 1 \mathrm{H}), 1.55(\mathrm{~s}, 3 \mathrm{H}), 1.43(\mathrm{~d}, J=7.2 \mathrm{~Hz}, 3 \mathrm{H}) ;{ }^{13} \mathrm{C}$ NMR $\left(125 \mathrm{MHz} ; \mathrm{CD}_{3} \mathrm{OD}\right): \delta 179.3,170.0,146.5,131.7$ (q, $J=31.0 \mathrm{~Hz}), 131.4,130.3,124.6(\mathrm{q}, J=3.8 \mathrm{~Hz}), 124.1(\mathrm{q}, J=3.8 \mathrm{~Hz}), 124.2(\mathrm{q}, J=272.6 \mathrm{~Hz}), 50.3,50.0,42.3,40.4$, 36.6, 24.3, 15.2; ${ }^{19} \mathrm{~F}$ NMR (470 MHz, $\mathrm{CD}_{3} \mathrm{OD}$ ): $\delta$ 64.0; HRMS (ESI, negative) for $\mathrm{C}_{15} \mathrm{H}_{17} \mathrm{~F}_{3} \mathrm{~N}_{2} \mathrm{O}_{3}(\mathrm{~m} / \mathrm{z}$ ): calculated $329.1108(\mathrm{M}-\mathrm{H})^{-}$, found 329.1117 ; HPLC purity $95.5 \%$, retention time $7.91 \mathrm{~min}$.

Biology. MMP-1 inhibitory assay was performed using the assay kit according to the manufacturer's protocol. A 96-well clear microplate (1/2 volume), $30.6 \mathrm{U} / \mu \mathrm{L}$ of MMP-1 enzyme, MMP-1 substrate (25 mM in DMSO), and colorimetric assay buffer were contained in MMP1 Inhibitor Screening Assay Kit (ab139443, abcam). 2-[(2-Methylpropyl) [(4-methoxyphenyl)sulfonyl] amino] acetohydroximic acid (NNGH) was used as a positive control of an MMP-1 inhibitor. The MMP-1 substrate and DMSO solution of compound were thawed at room temperature. A compound (10 mM in DMSO) was diluted at $1 / 200$ in assay buffer and brought to $37^{\circ} \mathrm{C}$. Also, the MMP- 1 substrate was diluted at $1 / 200$ in assay buffer and brought to $37^{\circ} \mathrm{C}$. The MMP-1 enzyme was diluted at $1 / 25$ in assay buffer and warmed up to $37^{\circ} \mathrm{C}$ as soon as the assay was started. After the assay buffer was pipetted appropriately into each well, $20 \mu \mathrm{L}$ of the prepared MMP-1 enzyme solution and the desired concentration of test inhibitor solutions $(20 \mu \mathrm{L}$; final concentrations: $0.1-100 \mu \mathrm{M})$ were added to the wells. The microplate was incubated for $30 \mathrm{~min}$ at $37^{\circ} \mathrm{C}$. The $10 \mu \mathrm{L}$ of the prepared MMP- 1 substrate solution was added into each well to allow the reaction start. The absorbance of the wells was measured at $\mathrm{A}_{412 \mathrm{~nm}}$ using a microplate reader every $1 \mathrm{~min}$, and data analysis was performed.

Pharmacophore fitting. To predict binding interaction between compounds and MMP-1, a pharmacophore model was constructed from the crystal structure of SC44463/MMP-1 (PDB: 1FBL) using LigandScout 4.4 (InteLigand $\mathrm{GmbH}$ ). Then, three pharmacophore features of SC44463 were used including a hydrogen bond acceptor (HA), hydrophobic (Hy) moiety, and zinc binding location feature (ZL). For pharmacophore evaluation, the scoring function was set to 'Relative Pharmacophore-Fit'. For all other parameters, default values were used. Compounds were fit to the SC44463 pharmacophore model followed by interaction energy minimization with MMP-1.

Received: 22 February 2020; Accepted: 19 August 2020

Published online: 07 September 2020

\section{References}

1. Wassermann, A. M., Wawer, M. \& Bajorath, J. Activity landscape representations for structure-activity relationship analysis. J. Med. Chem. 53(23), 8209-8223 (2010).

2. Peltason, L., Iyer, P. \& Bajorath, J. Rationalizing three-dimensional activity landscapes and the influence of molecular representations on landscape topology and the formation of activity cliffs. J. Chem. Inf. Model. 50(6), 1021-1033 (2010).

3. Medina-Franco, J. L., Yongye, A. B., Pérez-Villanueva, J., Houghten, R. A. \& Martínez-Mayorga, K. Multitarget structure-activity relationships characterized by activity-difference maps and consensus similarity measure. J. Chem. Inf. Model. 51(9), 2427-2439 (2011).

4. Stumpfe, D. \& Bajorath, J. Exploring activity cliffs in medicinal chemistry. J. Med. Chem. 55(7), 2932-2942 (2012).

5. Stumpfe, D. \& de la Vega de León A, Dimova D, Bajorath J, ,. Advancing the activity cliff concept, part II. F1000Research 199, 1-11 (2014).

6. Wassermann, A. M., Haebel, P., Weskamp, N. \& Bajorath, J. SAR matrices: automated extraction of information-rich SAR tables from large compound data sets. J. Chem. Inf. Model. 52(7), 1769-1776 (2012).

7. Zhang, L. et al. Novel methods for prioritizing "close-in" analogs from structure-activity relationship matrices. J. Chem. Inf. Model. 57(7), 1667-1676 (2017).

8. Free, S. M. \& Wilson, J. W. A mathematical contribution to structure-activity studies. J. Med. Chem. 7(4), 395-399 (1964).

9. Bajorath, J., Gupta-Ostermann, D., Hirose, Y., Odagami, T. \& Kouji, H. Follow-up: prospective compound design using the "SAR Matrix" method and matrix-derived conditional probabilities of activity. F1000Research 4(May), 1-15 (2015).

10. Jabłońska-Trypuć, A., Matejczyk, M. \& Rosochacki, S. Matrix metalloproteinases (MMPs), the main extracellular matrix (ECM) enzymes in collagen degradation, as a target for anticancer drugs. J. Enzyme Inhib. Med. Chem. 31, 177-183 (2016).

11. Dolor, A. \& Szoka, F. C. Digesting a path forward: the utility of collagenase tumor treatment for improved drug delivery. Mol. Pharm. 15(6), 2069-2083 (2018).

12. Sapadin, A. N. \& Fleischmajer, R. Tetracyclines: nonantibiotic properties and their clinical implications. J. Am. Acad. Dermatol. 54(2), 258-265 (2006).

13. Vandenbroucke, R. E. \& Libert, C. Is there new hope for therapeutic matrix metalloproteinase inhibition?. Nat. Rev. Drug Discov. 13(12), 904-927 (2014).

14. Gaulton, A. et al. The ChEMBL bioactivity database : an update. Nucleic Acids Res. 42, D1083-D1090 (2014). 
15. Nuti, E. et al. N-O-isopropyl sulfonamido-based hydroxamates: design, synthesis and biological evaluation of selective matrix metalloproteinase-13 inhibitors as potential therapeutic agents for osteoarthritis. J. Med. Chem. 52(15), 4757-4773 (2009).

16. Bertini, I. et al. Exploring the subtleties of drug-receptor interactions: the case of matrix metalloproteinases. J. Am. Chem. Soc. 129(9), 2466-2475 (2007).

17. Alberts, I. L., Todorov, N. P. \& Dean, P. M. Receptor flexibility in de novo ligand design and docking. J. Med. Chem. 48(21), 6585-6596 (2005).

18. Duan, J. J. W. et al. Discovery of $\gamma$-lactam hydroxamic acids as selective inhibitors of tumor necrosis factor a converting enzyme: design, synthesis, and structure-activity relationships. J. Med. Chem. 45(23), 4954-4957 (2002).

19. Moy, F. J. et al. Impact of mobility on structure-based drug design for the MMPs. J. Am. Chem. Soc. 124, 12658-12659 (2002).

20. Gimeno, A., Beltrán-debón, R., Mulero, M., Pujadas, G. \& Garcia-vallvé, S. Understanding the variability of the S1’ pocket to improve matrix metalloproteinase inhibitor selectivity profiles. Drug Discov. Today 25, 38-57 (2019).

\section{Acknowledgements}

This work was partially supported by Grants-in-Aid for "Chemistry for Multimolecular Crowding Biosystems (18H04542 to H. Nakamura)" and "Dynamic Alliance for Open Innovation Bridging Human, Environment and Materials" from MEXT, Japan.

\section{Author contributions}

Y.A., A.Y., and H.N. designed experiments; Y.A. synthesized and identified compounds; Y.A. and A.Y. carried out SARM study; J.B. and H.N. supervised the whole project; Y.A., J.B. and H.N. wrote the manuscript.

\section{Competing interests}

The authors declare no competing interests.

\section{Additional information}

Supplementary information is available for this paper at https://doi.org/10.1038/s41598-020-71696-2.

Correspondence and requests for materials should be addressed to J.B. or H.N.

Reprints and permissions information is available at www.nature.com/reprints.

Publisher's note Springer Nature remains neutral with regard to jurisdictional claims in published maps and institutional affiliations.

(c) (1) Open Access This article is licensed under a Creative Commons Attribution 4.0 International License, which permits use, sharing, adaptation, distribution and reproduction in any medium or format, as long as you give appropriate credit to the original author(s) and the source, provide a link to the Creative Commons licence, and indicate if changes were made. The images or other third party material in this article are included in the article's Creative Commons licence, unless indicated otherwise in a credit line to the material. If material is not included in the article's Creative Commons licence and your intended use is not permitted by statutory regulation or exceeds the permitted use, you will need to obtain permission directly from the copyright holder. To view a copy of this licence, visit http://creativecommons.org/licenses/by/4.0/.

(C) The Author(s) 2020 